\title{
REVIEW OF RISK ASSESSMENT AND OCCUPATIONAL HAZARD IN CONSTRUCTION INDUSTRIES AMID COVID -19 PANDEMIC
}

\author{
EDE CHRISTOPHER OKWUCHUKWU \\ CIVIL ENGINEERING DEPARTMENT, NAER EAST UNIVERSITY, \\ NICOSIA, CYPRUS. \\ Email:essisio007@gmail.com
}

DOI: $10.31364 / \mathrm{SCIRJ} / \mathrm{V} 9.105 .2021 . P 0521858$

http://dx.doi.org/10.31364/SCIRJ/v9.i05.2021.P0521858

$\begin{array}{lllllllllll}\text { A } & \mathbf{B} & \mathbf{S} & \mathbf{T} & \mathbf{R} & \mathbf{A} & \mathbf{C} & \mathbf{T} \text { - Corona virus infection and }\end{array}$ transmission has been a global challenge more specific to construction industries with workers daily toll to the virus infection rising. This concern made many researchers proposed range of ways to re-improved risk assessment strategy in other to identify, manage, and eliminate the virus at the workplaces without job satisfaction, security, and health of the worker being compromised, however, on the contrary these objectives of the researchers have not been addressed completely as allowing workers to undertake task together at the site would raise risk factor to the virus infection and substituting specific roles performed by human labour with artificial intelligence may proportionally lead to job losses, poverty and loss of dignity of human labour. In response to the above gap, this study investigates the review of industrial risk assessment and occupational hazards for safe return of workers to the site in response to corona virus infection across construction industries. The investigation uses industrial health hazard reports and statistics of two major countries with high risk of the virus transmission to compare the occupational fatalities during the pandemic and non-pandemic periods. The findings of this work showed that the number of industrial hazards proportional to low risk assessment factor were visibly high in construction industries than other occupations.

KEYWORDS: Risk Assessment, Fatality,Hazard Control,

Construction industry, Corona virus.

\subsection{INTRODUCTION}

After a convened research and innovative forum on covid19 which was attended by many experts and quite immensely about the intensity of spread, and its severity on the unsuspecting inactions of the world, the World Health Organization reached the assessment that covid-19 could be characterized as a global pandemic on $11^{\text {th }}$ march, 2020 (World Health organization,2020)[20]. A plague which has continued to account for more global deaths, and safely shields and measures in many industries the calls for new re-adjustment in the risk assessment approach and hazard control in work industries. For instance, known international forum on quality and safety in health care, had suggested health studies to united kingdom employers forum to take in responsibility of health and safety work Act, 1974, adopted to protect the lives of the workforce through few suggested guide posts for risk assessment procedure aimed towards identifying potential hazards, on what could lead to injury or illness and actions that must be preferred in other to eliminate hazards or possibly control risk.

The hazard and risk control of the special virus family corona viridae, SAR-COV-2 is extremely difficult to determine when it comes in terms of measuring the transmission rate in work places. These special features of the virus, informed views of different health agencies, industrial risk assessment management team and job safety evaluators to pin out means towards subduing the pandemic.

The transmission pattern of the virus informs the need for consideration when reviewing cases of the industrial hazards caused by the virus. Such key considerations, according to, [Office of the National Statistics and Health and Safety Executive, England [ONSHSE],2020)[13] need to be identified are: definitions of occupation and workplaces setting as well as assessing and analyzing, exposure, intensity of contacts and transmission among workers.

\subsection{RELATED STUDY}

In other to still maintains output distribution of goods, services, protect workers and preserve industrial chain, (Benjamin, 2001)[2] explains industrial risk as the chances that hazard could happen and hazard as the potentiality to cause harm and further identified those hazards as maintaining of good welfare facilities on the construction sites like proper water supply, good sanitary and washing facilities to eliminate contagious biological hazards but such wonderful ideas may not be feasible in a highly transmissible strain of variant species of coronavirus as 
well as other health safety protocols such as physical distancing likely not to be practicable in construction site where job safety analysis may require more than two persons or cluster. (OSH Answer Fact Sheet,2017) [14] describes industrial risk assessment as the whole process that involves identification of hazards, and its tendencies to cause harm as well as evaluating the risk involvement of that hazard in other to aid designing of appropriate measures for its control.

[International Labor organization (ILO,2020)[9] in her recently published guide policy titled covid-19 and new meaning of safety and health at work suggested constant labour inspection policy system a means of reducing work hazard. But work of (Dwayne et al ,2020)[6] and (Guilhermef, 2021)[8] opposed the views of (I LO, 2020) and [Benjamin, 2021] that supports face-to-face working condition with the introduction of fourth industrial resolution technology that eliminates disruption in production and distribution in the industries by introduction of artificial intelligence in the covid-19 era and thus lowering risk of infections.

The fourth industrial revolution at the intersection of readiness and responsibility (Deloitte,n.d)[5] explains industry fourth technology revolution as advanced technology of using internet, artificial intelligence, robot, drones, non-technology, cloud computing, 3.0 printing and more of these kinds to communicate, analyze, and process information which helps society, organization to be flexible in achieving their task or decision. Alternatively,(Carina et al, 2021)[3] believes that replacing human labour with fourth industrial technology revolution in other to control the spread of corona virus in work place as novel means of risk assessment and hazard control would not only undermine the actual role plays by human labour in work places but also could dig a gap of natural inequality that could bring huge defect in production capacity but, in contrast, suggests the exploration of the super smart society which aims at quality life and social challenge resolution.

The interactive and physical working condition was the opinion of (Rachael et al, 2020 )[16] which critically deduced re-introduction of new administration hazard and risk management measures to return workers safely to their jobs while maintaining health safety standard protocols at the site and whose idea was quite admitted by (Dana \& Anthony, 2020)[4] in their studies of application of industrial hygiene frame as a pivot for health and safety management among workers in the covid-19 era for risk assessment and control. Their hypothesis claimed that proper hygiene at the site could control biological hazard which was described and classified by (John, 1985)[10] as contaminated dust by fungi, bacteria, mist, and fumes responsible for lungs and respiratory infections called pneumonitis, nevertheless, such idea may be recommendable to hazard control of non- covid-19 biological hazard as this may not apply in a highly transmissible new variant strain of the virus so difficult to manage.

In all the views proposed by these authors, two questions are still not harmonized, firstly, if fourth industry technology is introduced in industry to reinforce risk assessment measurement and control hazard towards contracting the virus, more jobs would be lost, labour capital efficiency dampened, and poverty heightened, also if workers are returned to site putting health safety hygiene measures in places, there is likelihood that infection would be high since new variant-strain of the virus sar-covid- 2 is highly transmissible and unpredictable therefore appointing the purpose of this work which investigates the review of current industrial risk assessment and hazard control at the work sites to protect workers lives in the midst of corona virus spread.

\subsection{METHODOLOGY}

The study used quantitative research tools to examine few selected occupational surveys and Statistical reports for risk index measuring parameters of two major Countries where the wave of transmission was at high risk to deduce the findings and analyse the results. The data of real life occupation hazards fielded during the Coronavirus pandemic time was used to compare non-pandemic time industrial hazards of 2018. The report was further compared and narrowed to construction industries and other workplaces with high infectious disease hazards for risk evaluation and analysis. The data base of Bureau of Labour Statistics of the selected

Countries was accessed through online archive by specifying year of interest.

3.1 First step. General occupation hazards among California workers in pandemic time(18-65)years

Table I. Risk ratio and mortality in California during Pandemic time

\begin{tabular}{|c|c|c|c|}
\hline Job Code & Job Description & Death & Risk ratio \\
\hline 4020 & Cooks & 828 & 1.60 \\
\hline 8800 & $\begin{array}{l}\text { Packaging Filling } \\
\text { Machine }\end{array}$ & 172 & 1.59 \\
\hline 6050 & $\begin{array}{l}\text { Miscellaneous } \\
\text { workers }\end{array}$ & 617 & 1.55 \\
\hline 7800 & Bakers & 104 & 1.50 \\
\hline 6260 & Construction workers & 1587 & 1.49 \\
\hline 8965 & Production workers & 452 & 1.46 \\
\hline 8320 & $\begin{array}{l}\text { Sewing machine } \\
\text { operators }\end{array}$ & 127 & 1.44 \\
\hline 5610 & $\begin{array}{l}\text { Shipping receiving } \\
\text { traffic clerk }\end{array}$ & 146 & 1.44 \\
\hline 4250 & Ground maintenance & 712 & 1.40 \\
\hline 5240 & $\begin{array}{l}\text { Customers Service } \\
\text { Rep }\end{array}$ & 862 & 1.37 \\
\hline 4000 & Chef \&Head cooks & 532 & 1.33 \\
\hline 407 & Computer occupations & 136 & 1.33 \\
\hline 9600 & $\begin{array}{l}\text { Industrial trucks\& } \\
\text { tractors operators }\end{array}$ & 346 & 1.34 \\
\hline 3500 & $\begin{array}{l}\text { Licensed practical \& } \\
\text { License vocational } \\
\text { nursing }\end{array}$ & 109 & 1.34 \\
\hline 3930 & $\begin{array}{l}\text { Security guard gaming \& } \\
\text { survey Officer }\end{array}$ & 707 & 1.32 \\
\hline 6410 & $\begin{array}{l}\text { Property, real estate } \\
\text { \& comm. Association }\end{array}$ & 157 & 1.33 \\
\hline 4230 & $\begin{array}{l}\text { Maids and house- } \\
\text { keeping cleaners }\end{array}$ & 378 & 1.33 \\
\hline
\end{tabular}


3.2 Second Step.Correlation. Per 100,000 males or females in construction industries Correlated to fatalities in table I.

Table II. Survey of deaths in pandemic time per 100,000 workers in six selected occupations.

\begin{tabular}{|c|r|c|}
\hline Occupation & $\begin{array}{l}\text { Death per } \\
\text { 100,000 } \\
\text { males }\end{array}$ & $\begin{array}{l}\text { Deaths } \\
\text { per 100,000 } \\
\text { females }\end{array}$ \\
\hline $\begin{array}{l}\text { Sales \& } \\
\text { Customers servic }\end{array}$ & 156 & 111 \\
\hline $\begin{array}{l}\text { Industrial Operat } \\
\text { \&, } \\
\text { Construction wor }\end{array}$ & 827 & 24 \\
\hline $\begin{array}{l}\text { Skilled\& trade } \\
\text { Occupations }\end{array}$ & 848 & \\
\hline $\begin{array}{l}\text { Elementary } \\
\text { Occupations }\end{array}$ & 699 & \\
\hline $\begin{array}{l}\text { Administrative \& } \\
\text { Secretarial } \\
\text { Occupations }\end{array}$ & 186 & \\
\hline 3.3Third step. Persons and & \\
\hline
\end{tabular}

3.3Third step. Persons and equipment contacts compared with number of death hazards in table I\&II

Table III. Covid-19 hazards cases based on contacts in Selected categories in U.K.

\begin{tabular}{|c|c|c|c|}
\hline Workshop places & $\begin{array}{l}\text { Contacts } \\
\text { That } \\
\text { became } \\
\text { cases }\end{array}$ & $\begin{array}{l}\text { Total } \\
\text { Number } \\
\text { of close } \\
\text { contacts }\end{array}$ & $\%$ \\
\hline Military & 59 & 946 & $6.2 \%$ \\
\hline $\begin{array}{l}\text { Information and } \\
\text { communication }\end{array}$ & 143 & 233 & $6.1 \%$ \\
\hline Financial Services & 178 & 3.0 & $5.8 \%$ \\
\hline Arts, entertainmer & 123 & 2.6 & $5.7 \%$ \\
\hline Emergency Servid & 217 & 381 & $5.7 \%$ \\
\hline $\begin{array}{l}\text { Manufacturing or } \\
\text { Construction }\end{array}$ & 941 & 18, & $5.1 \%$ \\
\hline Civil Services & 223 & 414 & $5.0 \%$ \\
\hline $\begin{array}{l}\text { Food production } \\
\text { and Agriculture }\end{array}$ & 133 & 267 & $5.0 \%$ \\
\hline Transportation & 259 & 5,3 & $4.9 \%$ \\
\hline $\begin{array}{l}\text { Miscellaneous } \\
\text { Occupations }\end{array}$ & 1181 & 24, & $4.7 \%$ \\
\hline $\begin{array}{l}\text { Warehouse } \\
\text { Distribution }\end{array}$ & 221 & 4,7 & $4.6 \%$ \\
\hline Hospitality & 455 & 10 & $4.5 \%$ \\
\hline Health care & 640 & 14, & $4.5 \%$ \\
\hline $\begin{array}{l}\text { Work, Travel, } \\
\text { Activity } \\
\text { outside workplace }\end{array}$ & 34 & 852 & $4.0 \%$ \\
\hline Retail Sector & 669 & 17, & $3.9 \%$ \\
\hline $\begin{array}{l}\text { Critical national } \\
\text { infrastructure }\end{array}$ & 36 & 960 & $3.8 \%$ \\
\hline $\begin{array}{l}\text { Prison/detention } \\
\text { Facility }\end{array}$ & 34 & 985 & $3.5 \%$ \\
\hline $\begin{array}{l}\text { Immigration/ } \\
\text { boarder } \\
\text { forces service }\end{array}$ & 3 & 88 & \\
\hline $\begin{array}{l}\text { Close contacts } \\
\text { Service }\end{array}$ & 146 & 5,0 & \\
\hline $\begin{array}{l}\text { Drivers/sales } \\
\text { and } \\
\text { truck driver worke }\end{array}$ & 1962 & 913 & \\
\hline $\begin{array}{l}\text { Labourer,freight, } \\
\text { stick }\end{array}$ & 9620 & 25 & \\
\hline
\end{tabular}

WWW.scirj.org

(C) 2021, Scientific Research Journal

http://dx.doi.org/10.31364/SCIRJ/v9.i05.2021.P0521858

This publication is licensed under Creative Commons Attribution CC BY. standing as mean hazard $=1008$ )

3.4. Fourth step. Confirmation. Acute respiratory infections data due to covid-19 was examined to relate cases of contacts that turned infection in construction worksite in Liver pool.

Table IV. Acute respiratory hazards in workplace settings from August 2020 to Jan 2021 in Liver pool universities.

\begin{tabular}{|l|l|l|l|l|l|l|l|}
\hline Occupations & Aug. & Sept. & Oct. & Nov. & Dec. & Jan. & Total \\
\hline $\begin{array}{c}\text { Construction \& } \\
\text { Manufacturing }\end{array}$ & 19 & 108 & 194 & 163 & 73 & 129 & 686 \\
\hline Office & 13 & 128 & 207 & 115 & 82 & 117 & 662 \\
\hline Retailer & 21 & 124 & 132 & 58 & 87 & 99 & 521 \\
\hline $\begin{array}{c}\text { Distribution \& } \\
\text { Transportation }\end{array}$ & 9 & 55 & 105 & 67 & 65 & 91 & 392 \\
\hline $\begin{array}{c}\text { Manufacturing } \\
\text { \&Food packers }\end{array}$ & 16 & 54 & 77 & 59 & 33 & 64 & 323 \\
\hline \begin{tabular}{c} 
Restaurants \\
\hline Warehouse
\end{tabular} & 7 & 32 & 38 & 17 & 7 & 6 & 104 \\
\hline Military Sites & 1 & 17 & 28 & 8 & 19 & 15 & 94 \\
\hline
\end{tabular}

3.5 Fifth steps. Final indicial comparison: Statistics of 2018, total industrial hazards report was used as the index to evaluate the hazard statistics in table I, II, III and IV.

Table V. Hazard by contact events and exposure 2018(USA Bureau of Labor statistics, 2018) (Hint: Total hazards in construction industries in 2018 U.S.A

\begin{tabular}{|l|l|l|l|}
\hline Occupation & $\begin{array}{l}\text { Total } \\
\text { fatal } \\
\text { injury }\end{array}$ & $\begin{array}{l}\text { Harmful } \\
\text { exposure to } \\
\text { Environment }\end{array}$ & $\begin{array}{l}\text { Contact } \\
\text { with } \\
\text { objects } \\
\text { equipm }\end{array}$ \\
\hline $\begin{array}{l}\text { Agriculture, } \\
\text { factory \& } \\
\text { hunting }\end{array}$ & 200 & 33 & 167 \\
\hline $\begin{array}{l}\text { resources } \\
\text { \& Mining }\end{array}$ & 242 & 43 & 199 \\
\hline $\begin{array}{l}\text { Construction } \\
\text { sand } \\
\text { gravel mining }\end{array}$ & 2 & - & 2 \\
\hline $\begin{array}{l}\text { Stone mining } \\
\text { \& quarrying }\end{array}$ & 6 & - & - \\
\hline $\begin{array}{l}\text { Copper, Nickel, } \\
\text { lead, Zinc, } \\
\text { mining }\end{array}$ & 1 & - & 15 \\
\hline $\begin{array}{l}\text { Construction of } \\
\text { Building }\end{array}$ & 57 & 61 & 26 \\
\hline $\begin{array}{l}\text { Nonresidential } \\
\text { building }\end{array}$ & 21 & 6 & \\
\hline
\end{tabular}




\begin{tabular}{|c|c|c|c|}
\hline Construction & & & \\
\hline $\begin{array}{l}\text { Water and sewer } \\
\text { line } \\
\text { and related } \\
\text { Structure }\end{array}$ & 42 & 23 & 19 \\
\hline $\begin{array}{l}\text { Utility system } \\
\text { construction }\end{array}$ & 22 & 8 & 14 \\
\hline $\begin{array}{l}\text { Heavy and } \\
\text { civil engineering } \\
\text { Construction }\end{array}$ & 66 & 31 & 35 \\
\hline $\begin{array}{l}\text { Commercial and } \\
\text { Institution } \\
\text { Building }\end{array}$ & 17 & 4 & 13 \\
\hline $\begin{array}{l}\text { Oil and gas } \\
\text { pipeline } \\
\text { related structures }\end{array}$ & 3 & - & 3 \\
\hline $\begin{array}{l}\text { Power } \\
\text {,communication } \\
\text { line } \\
\text { \& related } \\
\text { Structures } \\
\text { construction } \\
\end{array}$ & 14 & 14 & - \\
\hline $\begin{array}{l}\text { Highway\& } \\
\text { bridge } \\
\text { construction }\end{array}$ & 15 & 4 & 11 \\
\hline $\begin{array}{l}\text { Foundation } \\
\text { structure } \\
\& \text { exterior } \\
\text { Construction }\end{array}$ & 66 & 36 & 30 \\
\hline $\begin{array}{l}\text { Residential } \\
\text { Construction }\end{array}$ & 35 & 23 & 11 \\
\hline $\begin{array}{l}\text { Structural steel\& } \\
\text { precast concrete }\end{array}$ & 8 & - & 8 \\
\hline $\begin{array}{l}\text { Residential } \\
\text { structural } \\
\text { steel and precast } \\
\text { Concrete } \\
\text { construction }\end{array}$ & - & - & - \\
\hline $\begin{array}{l}\text { Non- residential } \\
\text { structural steel } \\
\text { \& Precast } \\
\text { concrete } \\
\text { structures }\end{array}$ & 2 & - & 2 \\
\hline $\begin{array}{l}\text { Roofing } \\
\text { Construction }\end{array}$ & 19 & 19 & - \\
\hline $\begin{array}{l}\text { Building } \\
\text { equipment } \\
\text { Construction }\end{array}$ & 32 & 14 & 18 \\
\hline $\begin{array}{l}\text { Electrical } \\
\text { Construction }\end{array}$ & 33 & 29 & 4 \\
\hline $\begin{array}{l}\text { Plumbing, heating } \\
\& \\
\text { air conditioning } \\
\text { Contractors }\end{array}$ & 19 & 11 & 8 \\
\hline $\begin{array}{l}\text { Drywall \& } \\
\text { Insulation } \\
\text { Contractors } \\
\end{array}$ & - & - & - \\
\hline $\begin{array}{l}\text { Painting \& walling } \\
\text { Covering } \\
\text { Construction }\end{array}$ & - & - & - \\
\hline $\begin{array}{l}\text { Carpentry } \\
\text { Construction }\end{array}$ & 3 & 3 & - \\
\hline Site preparation const & 41 & 6 & 35 \\
\hline $\begin{array}{l}\text { General } \\
\text { construction }\end{array}$ & 342 & 173 & 169 \\
\hline
\end{tabular}



Fig I. Represents the bar chart data of occupational mortality during Covid-19 pandemic using 18-65 age limits of

California residents,USA.vertical axis represents $=$ hazard index

\subsection{Standard deviation comparison for hazard fatalities of construction workers in table I with table $V \&$ hint in table V}

Total fatality in construction industries during pandemic period in California, $2020=1587$

Total hazards in construction industries in 2018 U.S.A standing as mean hazard $=1008$ fatalities

\subsubsection{Standard deviation of section 4.1}

$=579$ fatalities

Table VI. Hazards infection due to harmful exposure to contagious environment in 2018, USA, and 2020,Liverpool.

A

\begin{tabular}{|c|c|c|c|}
\hline $\begin{array}{l}\text { Selected } \\
\text { construction } \\
\text { occupations } \\
\text { in2018,USA }\end{array}$ & $\begin{array}{l}\text { Sum } \\
\text { environment } \\
\text { exposure } \\
\text { hazard } \\
\text { infection, } \\
\text { 2018,USA } \\
\text { Construction } \\
\text { Industry }\end{array}$ & $\begin{array}{l}\text { Sum } \\
\text { Environment } \\
\text { acute } \\
\text { respiratory } \\
\text { infection, } \\
\text { construction } \\
\text { work, } \\
\text { Liverpool }\end{array}$ & $\begin{array}{l}\text { Recorded } \\
\text { months, } \\
\text { Liverpool }\end{array}$ \\
\hline $\begin{array}{l}\text { Building } \\
\text { Construction }\end{array}$ & 31 & 19 & Aug.,2020 \\
\hline $\begin{array}{l}\text { Water, sewer- } \\
\text { line } \\
\text { \&related- } \\
\text { Structure } \\
\text { Construction }\end{array}$ & 23 & 108 & Sept.,2020 \\
\hline $\begin{array}{l}\text { Highway, \& } \\
\text { bridge } \\
\text { construction }\end{array}$ & 4 & 194 & Oct.,2020 \\
\hline $\begin{array}{l}\text { Structural } \\
\text { steel\& } \\
\text { precast con- } \\
\text { crete }\end{array}$ & - & 163 & Nov.,2020 \\
\hline $\begin{array}{l}\text { Site } \\
\text { preparation } \\
\text { construction }\end{array}$ & 6 & 23 & Dec.,2020 \\
\hline $\begin{array}{l}\text { Roofing } \\
\text { Construction }\end{array}$ & 19 & 129 & Jan.,2021 \\
\hline
\end{tabular}


Parts A \&B ,represent USA and Liverpool.

The result compares parts A\&B.

The modal hazard infection to exposure in construction industry, USA, $2018=31$ hazards.

The modal hazards infection to acute respiratory infection due to exposure to infections in Liverpool construction workers = 194 0n October, 2020.

Total infectious exposures in part $\mathrm{A}=83$.

Total infectious exposure in part $\mathrm{B}=686$.

\subsection{Percentage $(\%)$ of total infections to harmful environment in parts $\mathrm{A} \& \mathrm{~B}$}

4.2.1. Part A $\%=10.79 \%$

4.2.2. Part B $\%=89.21 \%$

4.2.3. $\%$ in deviation in total infections to harmful environment in both A\& B parts $=78.42 \%$

4.2.4. Percentage ratio of infection in $\mathrm{A} \& \mathrm{~B}$ parts $=1: 8.28$

Table VII:defined work categories with highest infectious disease of covid- 19 hazard cases on contacts.

\begin{tabular}{|l|l|l|l|}
\hline Workplace & $\begin{array}{c}\text { Total } \\
\text { Contact }\end{array}$ & $\begin{array}{l}\text { Contact that } \\
\text { Turned Cases }\end{array}$ & Pie Chart value \\
\hline Health Care & 14313 & 640 & $48.10^{0}$ \\
\hline Retail Sellers & 17,021 & 669 & $50.3^{0}$ \\
\hline Hospitality & 10,121 & 455 & $34.2^{0}$ \\
\hline $\begin{array}{l}\text { Manufacturing } \\
\text { /Construction }\end{array}$ & 18,320 & 941 & $70.7^{0}$ \\
\hline $\begin{array}{l}\text { Office, } \\
\text { Administrative } \\
\text { \&Support } \\
\text { workers }\end{array}$ & 5940 & 125 & $9.4^{0}$ \\
\hline $\begin{array}{l}\text { Drivers/ sales } \\
\text { workers }\end{array}$ & 9130 & 1962 & $147.4^{0}$ \\
\hline
\end{tabular}

\section{Contact Cases}

\author{
- Health Care \\ - Retail Sellers \\ Hospitality \\ - Manufacturing/construction \\ - office,Admin\& Support workers \\ Drivers/ Sales workers
}

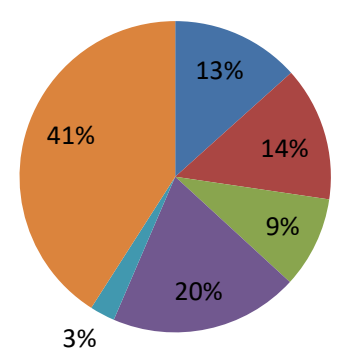

Fig. 2. Pie chart diagram of cases of contacts to corona virus hazards that became cases of table vii

\subsection{DISCUSSION:}

The bar chart shows that construction industry recorded the highest number of fatalities (1587) due Coronavirus infections at the site, followed by agriculture, Bakers with the least casualties of (104). In the occupational hazard index of (200), packaging and filling workers recorded the highest value of industrial fatality, for (400) maids, housekeepers, cleaners at more risk, to the (600) index, customer service representatives had highest fatality due to Covid-19 hazard, while cooks risk incidence rated 828 being second to highest in casualty. Considering the standard deviation in section 4.1 .1 , it reveals that the gap in total construction industry fatalities and infections to corona-virus recorded in California workers alone in the few selected age range (18-65 years) of the workers is by 579 higher than the total fatal hazards recorded among all the construction workers in U.S.A, 2018 pointing a progressive increase in incident cases in response to the surge in the wave of transmission among construction workers .

On table vi, the total number of infections to acute respiratory diseases is $78.42 \%$ higher and 8 times more than total hazards due to exposure recorded when the coronavirus has not struck.

Also, among all the workplaces examined to ascertain number of covid-19 contact cases that turned cases, 
construction/ manufacturing workers occupied second largest number of cases as clearly indicated in pie chart table vii with 70.7 which is about $19.6 \%$ area of circumference in the pie chart and, $21.3 \%$ less than $147.4^{0}$ number of contacts that became cases in drivers workers and approximately $5.6 \%$ more than retail sellers the third highest contacts that turned cases, this implied the reason why 2 . industrial plants and machine operatives in construction firms showed the second highest number of deaths in pandemic time drawn from survey of number of deaths per 100,000 males across occupations.

\section{CONCLUSION}

Conclusively, the findings clearly demonstrate that work health and safety measure currently carried out at various construction sites of different job categories are not being effective in stopping the risk of infections to the virus consequently bringing to the fore the necessity why site supervisors, health monitoring evaluators and labour organizations should start working towards reviewing the present means of risk assessment management procedures practice at the site in other to identify the corona virus hazard and design effective control mechanisms to eliminate it. The research is also suggested a source of future repository reference for infectiologist scientists such as epidemiologist, pathologist, virologist, ecologist, and other professional sciences to properly study the dynamics in terms of the virus mode of transmission, re-design for its protective devices, re-modify the existing safety and hygiene standards practised at the construction sites as well as provide for projected infectious diseases outlook that might affect workers efficiency in future.

\section{ACKNOWLEDGEMENT.}

I appreciate the effort of my lecturer,

Prof., Dr., Fatemeh Nouban for her academic guide during this work.

Am also thankful to the ever-ready presence of my Academic advisor, Prof., Dr,. Rifat Resatoglu, for his Continuous attention in my researchStudies. Finally, I appreciate the Near East University community for giving me the solid platform to perfect my studies.

May God bless all.
1. Andrew Watterson, "Covid-19 in the U.K and occupational health and safety: Predictable not inevitable failure by governmental organization and trade union and non-governmental organization responses," A Journal of Environmental and Occupational Health Policy, vol. 30,pp. 86-94, 2020. https://doi.org/10.1177/1048291120929763.

2. Benjamin. O. ALLI, "Fundamental principles of occupational health and safety," International Labour Office, Geneva,2020, pp. 1-30. in press.

3. Carina, A., Annibal, S., and Augusto, R, "Applying industrial 4.0 technologies in the covid-19 for sustainable supply chains," Emerald Insight Web,2021.

https://www.scibey.com

4. Dana H.,and Anthony-L. k, "Evaluating the industrial hygiene, toxicology, and public health," SageJournal,vol. 36, pp.605-606,2020.

https://doi.org/10.1177/0748233720964629

5. Deloitte Insights, (n.d). "The fourth industrial revolution At the intersection of readiness and responsibility," unpublished, https://www2.deloitte.com,

6. Dwayne,V.E.,Julie,B.,Arif,J.,Curtis,F.B.,\&and Gignac,A," Online resources supporting workers with chronic episodic disabilities: An environmental scan,"

International Journal of Work

Place Health Management,vol.14, pp. $129-148,2020$.

https://doi.org/10.1108/ijWHM-08-2020-0137

7. Episodic Disabilities Employment Network Canada, " About episodic disabilities," EDEN WEB,2016,

http : //www.edencanada.ca

8. Guilhermef, Frederico, "Towards a

Supply chain 4.0 on the Post - covid-19 pandemic: A conceptual and strategic discussion for more resilient supply," RAMJ Web,2021.

https://www.emerald.com

9. International Labor Organization, "Covid-19 and the new meaning of safely and health at Work," Ilostat Web, 2020. https://ilostat.ilo.org.

10. John. Mathew, " Health and safety at, $1^{\text {st }}$ edition," Pluto Press Australia,Limited,1985, pp. 217-366. in press.

11. Kamlesh, K., Amanda,G., Azeem, .M.,Chaand, N.,and Mala, R, "Accessing risk for health care workers during the covid-19 pandemic," Thebmj Web, 2021. https //www.bmj.com

\subsection{REFERENCE}

www.scirj.org

(C) 2021, Scientific Research Journal 
12. Malizagans, Mhango, Mathias, D., Itai, C., and Tafadzwa, D, "Covid-19 risk factors among health workers:A Rapid review," Science Direct,vol 11,pp. 262-265, 2020.

DOI: 10.1016/j.shaw.2020.06.001

13. Office for National Statistics \& Health and Safety Executive, England, "Covid-19 risk by occupation and workplace," Asset Publishing web,2021. https://assets. publishing.service.gov.uk.

14. OSH Answer Facts Sheet, "Risk assessment," Canadian Centre for Occupational Health and Safety Web,2017.

https: // www.ccohs.ca

15. Public Health England, "Covid-19 confirmed deaths in England (to 31 January 2021): Report," Public Health England Web,2021.

https:// www. gov.uk / government t/ publications / Covid - 19- reported -sars - cov -2-deaths - in - england /covid -19confirmed - deaths - in - england - report

16. Rachel. E. Z., Andrew M., Justine,P., Shannon G., Scott ,D., and Kenneth, U., " Accessing and managing the risk of covid-19 in the work place:Applying industyrial hygiene/occupational \&environmental health \& safety framework,"

Sage Journal ,vol.36, 607-618,2020. https://doi.org/10.1177/0748233720967522

17. .React-1, "Real-time assessment of community transmission of coronavirus in January 2021," Department of Health and Social Care Web,2021.

https : //www. gov .uk
18. Sergio L., Fabio B., Giuliana, B., Diana, G., Benedetta, P., Antonio V., and Bruna, M.R, "Risk assessment at work and prevention strategies on covid-19 in Italy," Plos One Journal,vol.10, pp. 1-11,2021. https://doi.org/10.1371/journal.pone.0248874

19. U.S. Bureau of Labour Statistics, " 2018 census of fatal occupational injuries: Industry by event or exposure2018(XLSX)," United States Government Web,2018. https :// www.bls.gov.

20.

World Health Organization," Achived: WHO timeline - covid-19," WHO Web,2020 https: //www.who.int. 